\title{
Talal Asad: para uma crítica da teoria do símbolo na antropologia religiosa de Clifford Geertz
}

\author{
Paula Montero
}

A religião como fenômeno sociológico tornou-se um a priori do pensamento social. Antropólogos e sociólogos tomam como autoevidente que a religião é essencialmente um conjunto de símbolos ligados a ideias gerais de ordem. Estas ideias se expressariam através de ritos ou doutrinas e constituiriam, na verdade, uma representação resultante de um processo histórico de longa duração centrado no cristianismo e suas mutaçóes. Esse é o ponto de partida que leva Talal Asad à proposição de uma antropologia histórica que busque compreender como a ideia de "religiáo" se tornou um conceito e uma prática no Ocidente moderno. No entanto, mais do que retomar essa genealogia tão bem realizada neste texto pelo autor, o foco de nosso interesse neste comentário introdutório será ressaltar as consequências teóricas dessa proposiçấo para uma teoria do simbólico e da significação no campo da antropologia.

Partindo da obra de Clifford Geertz "Religion as a Cultural System", Asad argumenta que a teoria antropológica naturalizou a ideia de religiáo como um fenômeno trans-histórico e transcultural a ponto de supor que sua essência própria e sua autonomia poderiam ser analiticamente identificáveis em qualquer circunstância. Segundo Geertz, toda religião poderia definir-se como um sistema de símbolos que motivam os comportamentos e sacralizam uma concepção geral de ordem. Desse modo, bastaria repertoriar os sentidos dos símbolos em operação em um determinado universo religioso e teríamos a chave de acesso à essência da religião.

Mas de que modo Geertz opera com o conceito de símbolo? Para Asad, este autor oscila entre dois entendimentos possíveis: considerar os símbolos apenas uma representação do real ou considerá-los um aspecto do próprio real. No segundo caso, o símbolo teria uma conexão intrínseca com o empírico, isto é, o símbolo seria o próprio objeto ou acontecimento que serve para carregar o sentido. No exemplo clássico que ele nos oferece a respeito da briga de galos balinesa temos a afirmação de que ela não seria "mera representação", mas sim a exibição mesma das paixốes de uma sociedade. No primeiro caso, teríamos uma separação entre representação e mundo empírico, isto é, o símbolo seria um objeto, ato ou acontecimento que remete a um significado que está fora dele. Em sua antropologia da religiáo Geertz, por exemplo, define símbolos enquanto "formulações tangíveis de noçóes abstratas (ideias, julgamentos, crenças) que visam comunicar uma concepção". Asad entende que essa oscilação confunde questốes cognitivas, da ordem da compreensão, com questóes comunicativas, da ordem do discurso.

Ao tomar os símbolos religiosos enquanto representaçôes, isto é, veículos de acesso a significados universais tais como o desejo de ordem e de superação da dor, Geertz generaliza o fenômeno 
religioso como dimensão cognitiva do humano que se expressa em uma dimensão cosmológica. Os símbolos religiosos ajudariam o homem a superar a inescapabilidade da dor, da injustiça, da ignorância inerentes à condição humana, conectando o plano da existência à esfera cósmica. $\mathrm{O}$ problema do significado, quando tratado nessa perspectiva que interpreta os símbolos religiosos como conceitos de ordem, moralidade e justiça, é que faz dos deuses, demônios, espíritos, etc. o campo da aplicação do sentido. Nessa versáo (bastante insípida no entender de Asad) do religioso como forma de encarar positivamente o mundo, de torná-lo suportável porque explicável, Geertz toma a crença como uma pulsão simbólica universal e reconhece como religiosa toda e qualquer prática ou pensamento que ocupe tal função cognitiva.

Em sua crítica à ideia de símbolo como objeto, ato ou acontecimento que remete a um significado, Asad sugere que os símbolos são modelados pelas práticas sociais. Desse modo, o objeto da investigação antropológica seria não tanto interpretá-los, mas sim compreender as condiçóes discursivas e não discursivas que os produzem e os tornam significativos uns em oposiçáo aos outros. Ao afirmar que os símbolos religiosos dáo sentido às condiçóes de vida e modelam o indivíduo, conferindo-lhe um conjunto de disposições, Geertz toma o mundo simbólico e o social como duas dimensóes separadas e supóe que os símbolos sozinhos podem produzir disposiçóes e práticas. Ao colocar em foco os processos (e não tanto os símbolos), Asad propóe não destacar sistemas simbólicos e práticas. Para ele, as práticas, as disposições e as ideias são ininterruptamente articuladas entre si através de formas de enunciação que visam a produzir sua legitimidade. A análise das formas de enunciação deve considerar que a natureza dos discursos é bastante variada se levarmos em conta suas diversas funções e/ou destinatários. Temos, por exemplo, os discursos que visam a orientar ou produzir um tipo de prática; há os que pretendem apenas descrever o mundo das coisas; há discursos que falam sobre algo e que são diferentes dos que falam para alguém, etc. Mesmo no campo religioso seria possível distinguir formas discursivas diferenciadas, tais como o discurso moral, o discurso litúrgico, o discurso teológico, etc., que se articulariam de maneira bastante diferenciada com a prática.

Em seu modo de separar símbolos e práticas, Geertz pretende que se possa definir uma prática como sendo religiosa em função de sua motivação: o ascetismo seria uma prática religiosa quando orientado pela ideia de nirvana, e secular quando orientado para um desejo de emagrecimento. Ao procurar diferenciar dessa maneira as disposiçóes seculares das religiosas, Geertz estaria reproduzindo, sem percebê-lo, o modo como a Igreja, historicamente, sempre procurou distinguir, pela autoridade de seu discurso oficial, a verdade (religiāo) da falsidade (subversão da religião ou definição do que estava fora da religião). Asad argumenta que todo tipo de prática pode ser incorporada a um sistema cosmológico, desde que processos de enunciação, em seus vários campos, tornem legítimas essas redefiniçóes. No caso da história do Ocidente, a disciplina foi, durante muitos séculos, a única prática religiosa reconhecida e regulada; posteriormente, na Idade Moderna, a concepção de prática religiosa deslocou-se progressivamente para o modo das crenças, isto é, conjunto de proposiçóes às quais os crentes dariam seu assentimento. Asad demonstra em seu texto como esse deslocamento correspondeu a um conjunto de transformaçóes históricas que, em resposta a problemas específicos da teologia cristâ, levaram à construção filosófica da ideia de "religião natural", e como esse passo foi importante para a formação dos conceitos de crença, experiência e prática. Do mesmo modo, Geertz também assume o ponto de vista da teologia quando dá primazia ao significado em detrimento da análi- 
se dos processos que produzem as significaçóes. Vejamos como isso afeta as bases heurísticas de uma antropologia da religiáo.

Vimos que, em sua compreensão do simbólico, Geertz confunde o discurso envolvido nas práticas e o discurso sobre as práticas. Isso o faz pressupor que o praticante agiria em funçáo de uma visão clara do quadro cosmológico que as determina ou que teria consciência da motivação teológica de suas açôes. Ora, Asad chama nossa atenção para o fato de que é preciso distinguir os processos simbólicos envolvidos nas práticas e os processos simbólicos que as inscrevem em um quadro cosmológico. Essa indistinção tem a ver com a obliteração do modo como a disciplina antropológica em formação herdou historicamente os procedimentos discursivos das práticas missionárias cristâs. No campo da ação evangelizadora cristá, o nativo foi observado e descrito a partir de suas práticas: era preciso decifrar os verdadeiros significados obscurecidos por detrás da aparente absurdez de seus ritos. $\mathrm{O}$ rastreamento das religióes nativas constitui-se, portanto, em uma operação simbólico-discursiva que visava, ao mesmo tempo, atribuir um significado aceitável às práticas e julgar a validade cosmológica de suas proposiçôes quando elas pareciam afirmar algo sobre o mundo. $\mathrm{O}$ modo como a antropologia incorporou para si essa teoria da religiáo a fez reproduzir acriticamente o suposto de que para dotar de sentido as práticas observáveis é preciso interpretá-las à luz de um pano de fundo exegético ou cosmológico.
A sugestão mais desafiadora de Asad neste ensaio está na proposição de que a antropologia, para compreender as relaçóes entre teoria e prática, abandone seu viés cognitivista, no qual o observador pensa poder definir o sentido das práticas de um ponto de vista exterior a elas. Em sua formulação, toda definiçãa é uma forma de intervençáo que, ao interpretar sentidos verdadeiros, excluir ou incluir proposiçóes e práticas, constrói a religião (ou a cosmologia) no mundo e não na mente dos indivíduos. $\mathrm{O}$ problema da abordagem geertziana (e de grande parte da abordagem antropológica em geral) seria sua forma particular de incorporar a concepçáo de crenças oriunda da modernidade cristá - algo interiorizado e privado, um estado mental distintivo e presente em todas as formas de religião - ao invés de percebê-las como uma atividade "constitutiva do mundo". E mais, esse processo discursivo de constituição da religião no mundo, ação continuada por meio da qual as proposiçóes religiosas ganham veracidade, não depende exclusivamente do modus operandi das representaçóes propriamente religiosas, mas, ao contrário, inclui forças, discursos e procedimentos disciplinares oriundos de campos historicamente distintos. Desse modo, em seu esforço para problematizar a definição de religiấo consensualmente aceita pela antropologia, Asad propóe que ela volte sua atenção para os processos disciplinares que autorizam (ou náo) a leitura dos símbolos e o modo como esses conceitos organizam a experiência.

autora Paula Montero

Professora Titular de Antropologia / USP

Pesquisadora do Cebrap

Recebido em 05/10/2010

Aceito para publicação em 05/10/2010

cadernos de campo, São Paulo, n. 19, p. 259-261, 2010 